\title{
REVIEW
}

\section{Role of neutrophils in systemic autoimmune diseases}

Mariana J Kaplan

\begin{abstract}
Neutrophils have emerged as important regulators of innate and adaptive immune responses. Recent evidence indicates that neutrophils display marked abnormalities in phenotype and function in various systemic autoimmune diseases, and may play a central role in initiation and perpetuation of aberrant immune responses and organ damage in these conditions. This review discusses the putative roles that neutrophils and aberrant neutrophil cell death play in the pathogenesis of various systemic autoimmune diseases, including systemic lupus erythematosus, small vessel vasculitis and rheumatoid arthritis.
\end{abstract}

\section{Introduction}

Neutrophils, terminally differentiated cells with a short lifespan in circulation, are the most abundant leukocytes in the human body, with homeostasis maintained by their continuous release from the bone marrow. More than $50 \%$ of the bone marrow is devoted to neutrophil production. As a first line of defense against invading microorganisms, neutrophils are characterized by their ability to act as phagocytic cells, release lytic enzymes from their granules and produce reactive oxygen species. In addition to microbial products, other stimuli (for example, tissue deposition of immune complexes) can induce the respiratory burst, leading to enhanced inflammation and the recruitment of inflammatory cells [1].

The neutrophil-mediated inflammatory response is a multistep process, initially characterized by adhesion of granulocytes to the activated vasculature, followed by their extravasation and migration towards inflamed

\footnotetext{
Correspondence: makaplan@umich.edu

Division of Rheumatology, Department of Internal Medicine, University of Michigan Medical School, 5520 MSRBI, 1150 W. Medical Center Drive, Ann Arbor, Ml 48109-560, USA
}

tissues, then leading to in situ destruction of microorganisms [2-4]. Upon homing to inflamed tissues, neutrophils engage in complex bidirectional interactions with macrophages, dendritic cells (DCs), natural killer cells, lymphocytes and mesenchymal stem cells, thereby influencing innate and adaptive immune responses [5,6]. Indeed, neutrophils can modulate DC maturation and, in turn, the proliferation and polarization of $\mathrm{T}$ cells [7]. Further, they can directly prime antigen-specific Thelper type 1 and T-helper type 17 cells [8]. Recent evidence also implicates splenic neutrophils in the development and establishing of specific phenotypes in marginal-zone B cells through cytokine effects, including immunoglobulin class switching, somatic hypermutation and antibody production [9]. In addition, several innate and adaptive immune cells can modulate neutrophil function [10,11].

Neutrophils may also display immunoregulatory roles in vivo at both peripheral sites and lymph nodes by synthesizing soluble mediators, decoy receptors and scavengers that promote downregulation of deleterious responses [12,13]. The disposal of apoptotic neutrophils is an important step in the resolution of inflammation and is regulated by the expression of eat-me signals, which shape the phenotype of engulfing macrophages [14].

Neutrophils are characterized by two distinctive morphological characteristics: the shape of their nucleus and their granules, which provide sequential release of bactericidal proteins into the extracellular space. Granules are classified into four groups: primary or azurophilic, secondary or specific, tertiary or gelatinase, and secretory vesicles. A wide variety of stimuli induce neutrophil degranulation, including $\mathrm{C} 5 \mathrm{a}$, formyl-methionylleucyl-phenylalanine, lipopolysaccharide, plateletactivating factor, and TNF. Neutrophils also express Toll-like receptors TLR1 to TLR10, with the exception of TLR3, enabling them to initiate various potentially important immune responses upon recognition of pathogen-associated molecular patterns $[2,4,15]$. 
Among some of the molecules present in the primary granules is a group called the alarmins, endowed with the capacity to rapidly engage antigen-presenting cells and activate innate and adaptive immune responses [16]. Neutrophil-derived alarmins include a number of human antimicrobial peptides such as $\alpha$-defensins, cathelicidin and lactoferrin. Further, neutrophil injury results in the release of nuclear binding proteins with alarmin activity, such as high-mobility group box-1 protein. The cathelicidin peptide LL-37, produced by proteolytic cleavage of the C-terminal antimicrobial domain of hCAP18, is chemotactic to various leukocytes. Other molecules released by neutrophils, including myeloperoxidase (MPO), neutrophil elastase and cathepsin G, also have important roles in triggering aberrant inflammatory responses [16]. Additionally, neutrophils synthesize eicosanoids and various inflammatory cytokines. Pertinent to autoimmune responses, although not usually considered classic IFN $\alpha-$ producing cells, neutrophils are capable of synthesizing this cytokine and other type I interferons in response to certain stimuli, including granulocyte colony-stimulating factor, or via double-stranded RNA helicase signaling pathways $[17,18]$. However, these observations relate to mRNA levels and there is some evidence that this may not translate into protein synthesis [19]. Future studies are needed to further address this controversy, particularly when related to lupus-specific stimuli.

In addition to granule release, neutrophils are efficient phagocytes and engulf microbes into phagosomes that rapidly fuse with the granules, exposing microorganisms to proteases, phospholipases and cationic peptides [20]. Neutrophils can also immobilize pathogens extracellularly by releasing neutrophil extracellular traps (NETs) (Figure 1) [21]. These traps are networks of extracellular fibers, primarily composed of DNA and various bactericidal proteins (neutrophil elastase, histones, and so forth), which bind and disarm pathogens [21-24]. During NET formation, neutrophils may die through a distinct cell death program termed NETosis [21]. NET formation appears to require NADPH oxidase (NOX) activity [25] as well as histone citrullination. The latter appears relevant for chromatin decondensation required for NET formation [26-28]. Indeed, neutrophils express high levels of nuclear peptidylarginine deiminase (PAD)-4, which catalyzes histone hypercitrullination, and mice lacking PAD-4 have decreased NET formation upon stimulation [25,27-29].

Various cytokines and chemokines play prominent roles in the recruitment, activation and survival of neutrophils at inflammatory sites, including IL-17, IL-8, IFN $\gamma$, TNF and granulocyte-macrophage colony-stimulating factor [30]. Conversely, human neutrophils are a source of cytokines that are important for the survival, maturation and differentiation of B cells, including BAFF and APRIL [9,31].

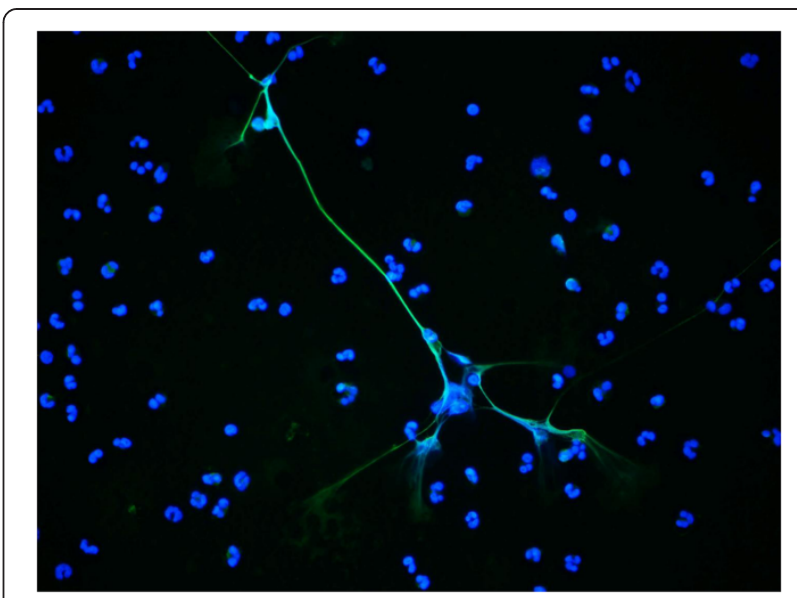

Figure 1 Representative images of neutrophil extracellular traps induced in vitro by lipopolysaccharide in human control neutrophils. Neutrophil extracellular traps are visualized by costaining of neutrophil elastase (green) and nuclear material (4',6-diamidino-2-phenylindole, blue). Original magnification 40x. Microphotograph obtained by Dr Ritika Khandpur.

While neutrophil responses eventually result in the successful resolution of inflammatory lesions, their recruitment and activation can become aberrant and lead to the development of disease states associated with tissue damage. To limit potentially excessive inflammatory responses, neutrophils are characteristically short-lived and die in circulation within 4 to 10 hours. However, the neutrophil lifespan can increase in response to cytokines or other proinflammatory agents [32]. Furthermore, recent data from in vivo labeling of human neutrophils with deuterium suggests a considerably longer half-life, averaging around 5 days in circulation, while murine neutrophils have a significantly shorter half-life [33].

Over the last several years, a renewed interest in the role that neutrophils play in various systemic autoimmune diseases has emerged. This review highlights the putative roles that neutrophils and aberrant neutrophil cell death play in several of these diseases, including systemic vasculitides, systemic lupus erythematosus (SLE) and rheumatoid arthritis (RA).

\section{Anti-neutrophil cytoplasm antibody-associated systemic vasculitis}

Anti-neutrophil cytoplasmic antibody-associated systemic vasculitis (AASV) comprises a group of systemic inflammatory vasculitides associated with circulating autoantibodies (anti-neutrophil cytoplasmic antibodies (ANCAs)) directed against the neutrophil granule components proteinase-3 (PR3) and MPO. AASV is characterized by leukocytoclasis and accumulation of unscavenged apoptotic and necrotic neutrophils in perivascular tissues. Indeed, injury in these conditions is largely driven by myeloid cells, including neutrophils. ANCAs interact with 
their target antigens on cytokine-primed neutrophils, causing neutrophil activation via several signaling pathways that lead to interaction with the endothelium, degranulation, cytokine production, and tissue damage. Given the presence of autoantibodies, the assistance of autoreactive T-helper cells and B cells appears to be required for disease to develop [34,35].

There are various proposed mechanisms by which ANCAs are pathogenic in this group of diseases. Priming of neutrophils with TNF induces PR3 and MPO translocation to the cell membrane, where they are accessible to autoantibody binding [36]. Anti-MPO and anti-PR3 antibodies cause neutrophil-dependent endothelial injury [37]. ANCAs bind to membrane-expressed target antigens and initiate intracellular signaling events. Fcgamma receptor $(\mathrm{Fc} \gamma \mathrm{R})$ interactions (including FcyRIIa and Fc $\gamma$ RIIIb) are involved in neutrophil activation by ANCAs, but additional putative pathways have also been described [38-40]. Anti-MPO IgG can cause pauci-immune glomerular necrosis and crescent formation in the absence of functional $\mathrm{T}$ lymphocytes or $\mathrm{B}$ lymphocytes in $\mathrm{Rag} 2^{-/-}$mice and in the presence of an intact immune system [41]. Chimeric $\mathrm{MPO}^{-/-}$mice with circulating MPO-positive neutrophils develop pauciimmune necrotizing and crescentic glomerulonephritis, while chimeric $\mathrm{MPO}^{+/+}$mice with circulating $\mathrm{MPO}$ negative neutrophils do not, suggesting that bone marrow-derived cells are necessary for induction of antiMPO disease [42]. In contrast, it has not been possible to induce similar phenotypes by passive transfer of antimouse-PR3 antibodies [43].

Human lysosome-associated membrane protein-2 (LAMP-2) has been identified as an additional target antigen in AASV. LAMP-2 is a heavily glycosylated type 1 membrane protein that is integrated into the membranes of neutrophil intracellular vesicles that contain MPO and PR3. Antibodies to human LAMP-2 have been reported to be highly prevalent in AASV and correlate with disease activity [44]. A passive model of antiLAMP2-mediated pauci-immune glomerular necrosis and crescent formation has been developed. The LAMP2 epitope recognized by human autoantibodies has 100\% homology to the bacterial adhesin FimH, with which it cross-reacts. Indeed, rats immunized with FimH develop a similar clinical phenotype and antibodies to rat and human LAMP-2 [45].

Dysregulation of neutrophil cell death has been proposed to contribute directly to the pathogenesis of AASV. Membrane PR3 expressed on apoptotic neutrophils has been proposed to amplify inflammation and promote autoimmunity by affecting the anti-inflammatory reprogramming of macrophages [46].

Polyclonal ANCAs isolated from patients and chimeric PR3-ANCA can trigger release of neutrophil microparticles that express PR3 and MPO and bind and activate endothelial cells. Neutrophil microparticles can also induce generation of thrombin, thereby promoting clot formation [47]. ANCA-activated neutrophils also release BLyS, which could contribute to the amplification of ANCA responses by inducing B-cell survival and plasma cell differentiation [48].

NETs are produced by ANCA-stimulated neutrophils and have been reported in glomeruli and in the interstitium of kidney biopsies from patients with AASV. NETosis results in elevated levels of PR3 and MPO that are contained in the NETs. Further, circulating MPODNA complexes have been detected in patients with AASV, suggesting that NET formation triggers vascular inflammation and promotes autoimmune responses against neutrophil components in these diseases [49].

Propylthiouracil, a drug used to treat hyperthyroidism, has been associated with the development of vasculitis. A recent study found that NETs formed in neutrophils exposed to propylthiouracil change their conformation and are less prone to be degraded by nucleases. Further, when these propylthiouracil-exposed netting neutrophils are transferred to rodent models, they elicit a AASV phenotype [50]. Finally, DCs cocultured with netting neutrophils internalize NET material and, when transferred to rodent models, induce a vasculitis-like syndrome [51]. These observations suggest that aberrant NETosis may be implicated in the pathogenesis of AASV.

\section{Systemic lupus erythematosus}

Several qualitative abnormalities in various neutrophil functions have been reported in SLE. Lupus neutrophils display impaired phagocytic capacity [52]. SLE serum induces increased neutrophil aggregation and interferes with phagocytosis and lysosomal enzyme release by control neutrophils [53]. Lupus neutrophils are activated intravascularly by autoantibodies and nucleosomes and display a tendency to form aggregates [54]. Differences in oxidative metabolism of neutrophils mediated by $\mathrm{Fc} \gamma \mathrm{R} / \mathrm{complement}$ receptor have been suggested as acquired characteristics of the disease that are associated with distinct clinical manifestations. However, this observation requires further confirmation [55]. Levels of various bactericidal proteins synthesized and released by activated neutrophils and/or their precursors are increased in lupus sera [56].

Increased numbers of apoptotic neutrophils are found in SLE, related to disease activity and levels of antidouble-stranded DNA (anti-dsDNA) antibody. AntidsDNA and anti-SS/B antibodies can modulate neutrophil cell death and function, respectively [57]. Neutrophils from SLE patients have a reduced ability to be recognized and removed by the $\mathrm{C} 1 \mathrm{q} /$ calreticulin/CD91- 
mediated apoptotic pathway, despite the presence of main apoptotic recognition partners [58]. Interestingly, there is recent evidence that various scavenger molecules show reduced binding to NETs [59]. ANCAs develop in SLE and are directed toward a number of neutrophil proteins, although their role in disease pathogenesis remains unclear (reviewed in [60]).

Neutropenia is a common feature in SLE and may be multifactorial, including neutrophil-reactive autoantibodydriven cell removal, neutralizing autoantibodies against neutrophil growth factors and myeloid precursors, bone marrow suppression, enhanced neutrophil apoptosis, secondary necrosis and NETosis. For a more comprehensive review on this specific complication, please refer to [61].

Significant upregulation of granulocyte-specific transcripts (granulocyte signatures) have been identified in the peripheral blood mononuclear cell fractions from SLE patients [62]. This is due to a subset of low-density granulocytes (LDGs) that are present in peripheral blood mononuclear cell fractions from adult and pediatric lupus patients. LDGs express similar cell-surface markers to mature autologous or healthy control neutrophils but differ from these cells in their nuclear morphology, which is consistent with an immature phenotype. LDGs appear to be proinflammatory; they synthesize higher levels of type I and type II interferons and TNF, and they display enhanced capacity to kill endothelial cells $[63,64]$.

Gene array studies have demonstrated higher mRNA levels of various immunostimulatory bactericidal proteins and alarmins present in azurophilic granules in the LDGs, relative to normal density SLE-derived and control neutrophils [65]. Given that levels of mRNAs that encode neutrophil serine proteases are highest at the promyelocytic stage in the bone marrow and decrease as these cells mature, it has been suggested that LDGs possess a more immature phenotype than normal-density neutrophils. This is supported by gene expression studies of SLE bone marrow, where a granulopoiesis-related signature is associated with disease activity [66]. As such, it is possible that LDGs represent an aberrant immature subset originating from the bone marrow that might persist or expand in the blood and/or other tissues in patients with SLE [64].

Recent evidence implicates aberrant NET formation, as well as impaired clearance of NET material, in lupus pathogenesis [65,67-69]. Increased NET formation has been reported in lupus neutrophils in the absence of infection. In particular, LDGs appear to be primed to form NETs ex vivo without needing additional stimuli [65]. These NETs externalize dsDNA and inflammatory cytokines, and levels of NETosis in the periphery and in tissues correlate with circulating anti-dsDNA titers. Indeed, affected skin and kidneys from patients with
SLE are infiltrated by neutrophils that are undergoing NETosis, thereby exposing autoantigens and proinflammatory molecules at the tissue level [65]. Lupus serum contains immune complexes composed of autoantibodies to antimicrobial peptides such as LL37 and human neutrophil peptides and anti-dsDNA, in association with NETs. These immune complexes block the degradation of self-DNA by nucleases, thereby promoting its uptake by plasmacytoid DCs [69]. Indeed, self-DNA triggers TLR9 activation in plasmacytoid DCs and promotes the synthesis of IFN $\alpha$, a cytokine that may prime further NET production [69]. Upon priming with IFN $\alpha$, anti-RNP antibodies induce NET formation in lupus neutrophils [67]. The degradation of NETs by DNase I, normally found in healthy human serum, is impaired in about one-third of SLE patients [68]. This finding correlates with high levels of antinuclear and antiNET antibodies and with higher prevalence of lupus nephritis and complement activation [70]. Indeed, NETs activate complement and the deposition of $\mathrm{C} 1 \mathrm{q}$ in these structures impairs their degradation [70]. NETs, and LL37 associated with the NETs, also stimulate the NLRP3 inflammasome machinery in lupus macrophages, which may further promote proinflammatory responses in various organs, including kidneys and vasculature, through IL-18 and IL-1 $\beta$ effects [71].

A role for aberrant NET formation in animal models of lupus has been the focus of recent investigations. Injection of netting neutrophil cell lines to nonlupus prone mice led to moderate anti-IgG and anti-IgM responses but did not trigger a clinical phenotype [72]. However, it is unclear whether second signals or specific priming factors would be needed for this phenomenon to occur and whether this approach truly mimics in vivo NET formation with regards to TLR signaling and other putative mechanisms implicated in immunogenicity [72]. In the $\mathrm{MRL} / \mathrm{lpr}$ mouse, knocking out NOX2 resulted in worsening lupus phenotype [73]. However, the role of NOX in immune responses is complex. For example, patients with chronic granulomatous disease and lack of functional NOX display a proinflammatory phenotype even if they are immunodeficient [74]. This may be related to the observation that NOX is important in preventing inflammasome activation in monocytes in addition to other anti-inflammatory roles [74,75]. Finally, whether all processes of NET formation require NOX has been challenged recently [76,77]. Nevertheless, these observations may support pleiotropic functions of NOX2, with potential immunoregulatory roles.

In the rat pristane model of autoimmunity, cathelicidin expression was also found in other organs (spleen, joints) and in association with low-density granulocytes in the blood. After pristane injection, the increased expression of rCRAMP (the mouse ortholog of LL37) 
coincided with higher levels of apoptosis, type I interferons and autoantibodies [78].

The NZM2328 lupus prone model displays evidence of enhanced NET formation in bone marrow neutrophils. Furthermore, factors present in NZM2328 sera induce NET formation in control neutrophils, and antiNET and anti-CRAMP antibodies have been detected in the sera of these mice [79]. Similarly to human biopsies, netting neutrophils infiltrate kidneys from NZM2328 mice and NETs directly impair endothelial function. When these mice were administered $\mathrm{Cl}$-amidine, an irreversible inhibitor of PAD enzymes (including PAD-4), they displayed decreased NET formation and significantly less deposition of immune complexes in the kidney and complement activation, while serum autoantibody levels increased, possibly due to lack of immune complex deposition in tissues. Furthermore, endothelial function, vascular repair and prethrombotic phenotype all improved when NETosis was inhibited in these mice [79]. These observations implicate PAD-4dependent pathways for NET formation as functionally relevant in lupus pathogenesis as well as in its associated vascular risk [79]. Future studies need to further address in additional models, using additional inhibitors and knockout systems, the specific role that NETs play in lupus pathogenesis.

Another important issue that requires future experimentation is better understanding the interplay of neutrophils in both susceptibility for infections and autoimmunity in the context of SLE, as suggested in specific murine models [80].

\section{Rheumatoid arthritis}

The identification of increased neutrophils in RA synovial fluid, particularly in early disease stages, supports a role for these cells in the pathogenesis of joint destruction [81-85]. Activated neutrophils have been found in RA synovial fluid, synovial tissue and RA-associated skin disease [86-89]. Anti-granulocyte antibodies and ANCAs have also been described in RA [90-92]. Further, there is a prominence of neutrophil recruitment in RA animal models [93-95], with critical roles for these cells in initiating and maintaining joint inflammatory processes described in collagen-induced arthritis [96]. Cathelicidins are strongly upregulated in RA synovial membranes and in joints from rats with arthritis, particularly in myeloid cells including neutrophils [78].

Various chemoattractants stimulate neutrophil migration from the peripheral blood to the joint in RA $[81,97]$. Neutrophils have been demonstrated to participate in their own recruitment in murine arthritis through $\mathrm{C} 5 \mathrm{aR}$ and $\mathrm{Fc} \gamma \mathrm{R}$ signaling [98]. Granulocyte colony-stimulating factor promotes neutrophil trafficking into inflamed joints and induces neutrophil production [99]. Granulocyte-macrophage colonystimulating factor has been found to be a key player in arthritis models, participating in interactions between hematopoietic cells through control of myeloid cell numbers and activation [100]. Dysregulation of T-helper type 17 responses in RA may play a role in increasing neutrophil recruitment to the joint [101]. In the $\mathrm{K} / \mathrm{BxN}$ transgenic mouse model of inflammatory arthritis, neutrophil recruitment into the joints is promoted by leukotriene B4 through its receptor BLT1, both of which are expressed by neutrophils [102]. Neutrophil activation by immune complexes in the joints promotes IL-1 $\beta$ production, which in turn stimulates synovial cells to produce chemokines, and this amplifies neutrophil recruitment into the joints [98]. PAD-4 mRNA, absent from healthy synovium, is transcribed and translated by neutrophils infiltrating synovial tissue during inflammation. As a consequence, several synovial proteins are citrullinated in this compartment, which may play a pathogenic role [103].

Various neutrophil function abnormalities have been reported in RA $[104,105]$. Exposure to immune complexes, rheumatoid factor and cytokines in synovial fluid results in neutrophil activation and granular content release that contributes to cartilage destruction [106-108]. The rheumatoid synovial joint contains a complex mixture of proapoptotic and antiapoptotic factors, and local oxygen tensions that exist within these joints can exert profound effects on neutrophil survival [109]. Neutrophil-derived cytokines are also involved in bone resorption. Indeed, neutrophils can upregulate expression of functionally active, membrane-bound receptor activator of NF-kB ligand [110] and this is increased in synovial fluid from active RA patients [111]. Remission of RA has been linked with changes in neutrophil adhesion and chemotaxis that may potentially decrease neutrophil migration to the synovial fluid, with subsequent improvements in the clinical manifestations of RA [112].

Circulating and synovial fluid RA neutrophils are more prone to form NETs when compared with neutrophils from healthy controls and from patients with osteoarthritis. Levels of NETosis correlate with the presence and levels of anti-citrullinated peptide antibodies and with markers of systemic inflammation [113]. Similar to what has been described above for anti-RNP [67] and ANCA antibodies [49], RA sera, synovial fluid, rheumatoid factor and IgG fractions purified from RA patients with high levels of anti-citrullinated peptide antibodies significantly enhance NET formation and lead to distinct protein content in the NETs [113]. NETs externalize citrullinated autoantigens implicated in RA pathogenesis, including citrullinated vimentin. In turn, purified anti-citrullinated vimentin antibodies potently induce NET formation. As additional triggers for enhanced 


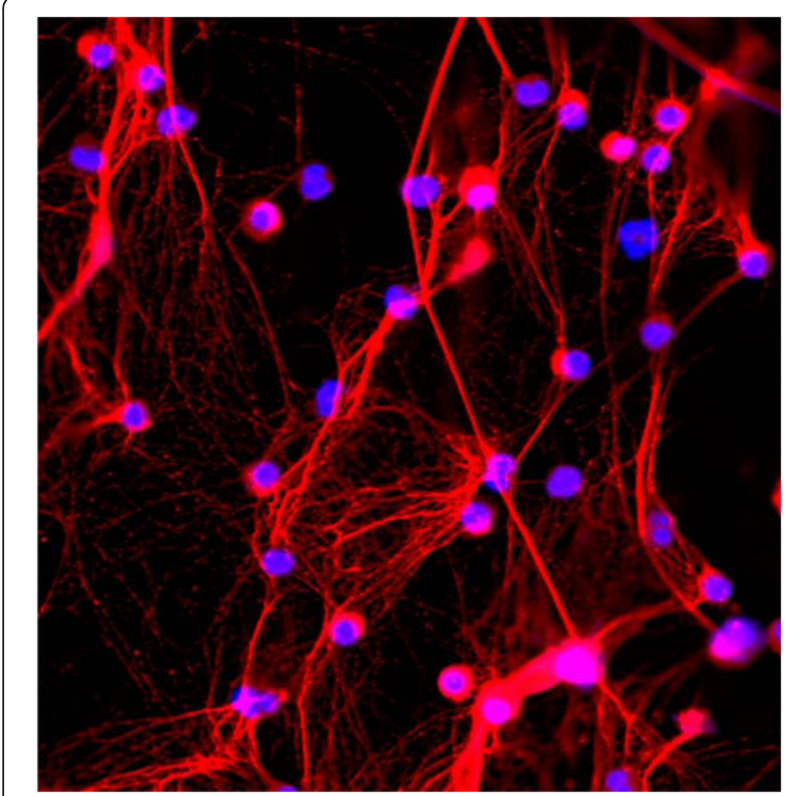

Figure 2 Neutrophil extracellular traps in neutrophils from a rheumatoid arthritis patient, following in vitro stimulation. Neutrophil extracellular traps (NETs) visualized in neutrophils isolated from a patient with rheumatoid arthritis, following stimulation with recombinant IL-17A in vitro. Prominent NET formation is displayed, with DNA visualized in blue (4',6-diamidino-2-phenylindole) and neutrophil elastase in red. Original magnification 40x. Microphotograph obtained by Dr Carmelo Carmona-Rivera.

NETosis in RA, IL-17A and TNF $\alpha$ were identified as putative factors (Figure 2) [113]. The implications for enhanced NETosis in RA pathogenesis were also suggested by identifying RA NETs as strong activators of synovial fibroblasts, leading to enhanced synthesis of proinflammatory cytokines, adhesion molecules and chemokines by these cells [113]. As such, accelerated NETosis may play a pathogenic role in RA through externalization of citrullinated autoantigens and immunostimulatory molecules. This could lead to the promotion of immune responses in the joint, blood and other tissues and could perpetuate pathogenic mechanisms in this disease. Recent evidence indicates that inflammatory loops initiated by molecules described to be externalized in NETs may be key in arthritis development [114]. Interestingly, antibodies to modified citrullinated vimentin are associated with severity of RA [115]. Confirmation of the impact of NETs in RA pathogenesis is required in animal models and using specific inhibitors. Of interest, a PAD inhibitor mitigates collageninduced arthritis [116]. However, no abrogation of disease severity was observed in PAD-4 knockout mice in the $\mathrm{K} / \mathrm{BxN}$ serum transfer model of arthritis [117].

In Felty's syndrome, a severe form of RA characterized by neutropenia and splenomegaly, circulating autoantibodies are preferentially directed against PAD-4 -deiminated histones and bind to activated neutrophils and NETs. These observations suggest a direct contribution of neutrophil activation and the production of NET-associated nuclear autoantigens in the initiation or progression of Felty's syndrome [118].

\section{Summary and conclusions}

Neutrophils have emerged as important regulators of innate and adaptive immune responses, display marked abnormalities in phenotype and function in various systemic autoimmune diseases, and may play a central role in initiation and perpetuation of aberrant immune responses and organ damage in these conditions. In addition to the use of ANCAs in AASV, there is a need to examine the role of neutrophils, anti-neutrophil antibodies, NETs and associated proteins as potential biomarkers that may predict development of tissue damage, autoantibody responses, vascular complications, and so forth. Important questions remain with regards to neutrophil diversity and plasticity that may be quite important to address with regards to induction of inflammatory responses and tolerogenic roles. In addition, better tools are needed to dissect the phenotype and function of neutrophils in vivo with respect to their role in autoimmunity. Future studies should also examine whether inhibition of aberrant NETosis will lead to amelioration of symptoms and prevent organ damage in patients with autoimmune disorders.

\section{Abbreviations}

AASV: Anti-neutrophil cytoplasmic antibody-associated systemic vasculitis; ANCA: Anti-neutrophil cytoplasmic antibody; DC: Dendritic cell; dsDNA: Double-stranded DNA; FcyR: Fcgamma receptor; IFN: Interferon; Ig: Immunoglobulin; IL: Interleukin; LAMP-2: Lysosome-associated membrane protein 2; LDG: Low-density granulocyte; MPO: Myeloperoxidase;

NET: Neutrophil extracellular trap; NF: Nuclear factor; NOX: NADPH oxidase; PAD: Peptidyl arginine deiminase; PR3: Proteinase-3; RA: Rheumatoid arthritis; SLE: Systemic lupus erythematosus; TLR: Toll-like receptor; TNF: Tumor necrosis factor.

\section{Competing interests}

The author declares that she has no competing interests.

\section{Acknowledgments}

This work was supported by the National Institutes of Health through PHS grant HL088419, the Alliance for Lupus Research and the Rheumatology Research Foundation. The author thanks Dr Ritika Khandpur and Dr Carmelo Carmona-Rivera for obtaining and providing pictures of netting neutrophils.

\section{Published: 02 Oct 2013}

\section{References}

1. Kessenbrock K, Frohlich L, Sixt M, Lammermann T, Pfister H, Bateman A, Belaaouaj A, Ring J, Ollert M, Fassler R, Jenne DE: Proteinase 3 and neutrophil elastase enhance inflammation in mice by inactivating antiinflammatory progranulin. J Clin Invest 2008, 118:2438-2447.

2. Borregaard N, Sorensen OE, Theilgaard-Monch K: Neutrophil granules: a library of innate immunity proteins. Trends Immunol 2007, 28:340-345.

3. Huber AR, Kunkel SL, Todd RF 3rd, Weiss SJ: Regulation of transendothelial neutrophil migration by endogenous interleukin-8. Science 1991, 254:99-102.

4. Borregaard N: Neutrophils, from marrow to microbes. Immunity 2010, 33:657-670 
5. Jaeger BN, Donadieu J, Cognet C, Bernat C, Ordonez-Rueda D, Barlogis V, Mahlaoui N, Fenis A, Narni-Mancinelli E, Beaupain B, Bellanné-Chantelot C, Bajénoff M, Malissen B, Malissen M, Vivier E, Uqolini S: Neutrophil depletion impairs natural killer cell maturation, function, and homeostasis. J Exp Med 2012, 209:565-580.

6. Micheletti A, Costantini C, Calzetti F, Camuesco D, Costa S, Tamassia N Cassatella MA: Neutrophils promote 6-sulfo $\mathrm{LaCNAC}^{+}$dendritic cell (slanDC) survival. J Leukoc Biol 2013 [Epub ahead of print].

7. Park SJ, Burdick MD, Mehrad B: Neutrophils mediate maturation and efflux of lung dendritic cells in response to Aspergillus fumigatus germ tubes. Infect Immun 2012, 80:1759-1765.

8. Abi Abdallah DS, Egan CE, Butcher BA, Denkers EY: Mouse neutrophils are professional antigen-presenting cells programmed to instruct Th1 and Th17 T-cell differentiation. Int Immunol 2011, 23:317-326.

9. Puga I, Cols M, Barra CM, He B, Cassis L, Gentile M, Comerma L, Chorny A, Shan M, Xu W, Magri G, Knowles DM, Tam W, Chiu A, Bussel JB, Serrano S, Lorente JA, Bellosillo B, Lloreta J, Juanpere N, Alameda F, Baró T, de Heredia CD, Torán N, Català A, Torrebadell M, Fortuny C, Cusí V, Carreras C, Diaz GA, et al: B cell-helper neutrophils stimulate the diversification and production of immunoglobulin in the marginal zone of the spleen. Nat Immunol 2012, 13:170-180

10. Derycke L, Zhang N, Holtappels G, Dutre T, Bachert C: IL-17A as a regulator of neutrophil survival in nasal polyp disease of patients with and without cystic fibrosis. J Cyst Fibros 2012, 11:193-200.

11. Kinsey GR, Sharma R, Huang L, Li L, Vergis AL, Ye H, Ju ST, Okusa MD: Regulatory T cells suppress innate immunity in kidney ischemiareperfusion injury. J Am Soc Nephrol 2009, 20:1744-1753.

12. Schuster S, Hurrell B, Tacchini-Cottier F: Crosstalk between neutrophils and dendritic cells: a context-dependent process. J Leukoc Biol 2012 [Epub ahead of print].

13. Kasten KR, Muenzer JT, Caldwell CC: Neutrophils are significant producers of IL-10 during sepsis. Biochem Biophys Res Commun 2010, 393:28-31.

14. Ren Y, Savill J: Proinflammatory cytokines potentiate thrombospondinmediated phagocytosis of neutrophils undergoing apoptosis. J Immuno 1995, 154:2366-2374

15. Prince LR, Whyte MK, Sabroe I, Parker LC: The role of TLRs in neutrophil activation. Curr Opin Pharmacol 2011, 11:397-403.

16. Yang D, de la Rosa G, Tewary P, Oppenheim JJ: Alarmins link neutrophils and dendritic cells. Trends Immunol 2009, 30:531-537.

17. Shirafuji N, Matsuda S, Ogura H, Tani K, Kodo H, Ozawa K, Nagata S, Asano S, Takaku F: Granulocyte colony-stimulating factor stimulates human mature neutrophilic granulocytes to produce interferon-alpha. Blood 1990, 75:17-19.

18. Tamassia N, Le Moigne V, Rossato M, Donini M, McCartney S, Calzetti F, Colonna M, Bazzoni F, Cassatella MA: Activation of an immunoregulatory and antiviral gene expression program in poly $(\mathrm{l}: \mathrm{C})$-transfected human neutrophils. J Immunol 2008, 181:6563-6573.

19. Tamassia N, Cassatella MA: Cytoplasmic receptors recognizing nucleic acids and mediating immune functions in neutrophils. Curr Opin Pharmacol 2013, 13:547-554.

20. Nordenfelt $P$, Tapper $H$ : Phagosome dynamics during phagocytosis by neutrophils. J Leukoc Biol 2011, 90:271-284.

21. Brinkmann $V$, Reichard U, Goosmann C, Fauler B, Uhlemann Y, Weiss DS, Weinrauch Y, Zychlinsky A: Neutrophil extracellular traps kill bacteria. Science 2004, 303:1532-1535.

22. Brinkmann $V$, Zychlinsky A: Neutrophil extracellular traps: is immunity the second function of chromatin? J Cell Biol 2012, 198:773-783.

23. Remijsen Q, Kuijpers TW, Wirawan E, Lippens S, Vandenabeele P, Vanden Berghe T: Dying for a cause: NETosis, mechanisms behind an antimicrobial cell death modality. Cell Death Differ 2011, 18:581-588.

24. Kaplan MJ, Radic M: Neutrophil extracellular traps: double-edged swords of innate immunity. J Immunol 2012, 189:2689-2695.

25. Fuchs TA, Abed U, Goosmann C, Hurwitz R, Schulze I, Wahn V, Weinrauch Y, Brinkmann $V$, Zychlinsky A: Novel cell death program leads to neutrophil extracellular traps. J Cell Biol 2007, 176:231-241.

26. Hemmers S, Teijaro JR, Arandjelovic S, Mowen KA: PAD4-mediated neutrophil extracellular trap formation is not required for immunity against influenza infection. PLOS One 2011, 6:e22043.

27. Li P, Li M, Lindberg MR, Kennett MJ, Xiong N, Wang Y: PAD4 is essential for antibacterial innate immunity mediated by neutrophil extracellular traps. J Exp Med 2010, 207:1853-1862.
28. Wang Y, Li M, Stadler S, Correll S, Li P, Wang D, Hayama R, Leonelli L, Han H, Grigoryev SA, Allis CD, Coonrod SA: Histone hypercitrullination mediates chromatin decondensation and neutrophil extracellular trap formation. J Cell Biol 2009, 184:205-213.

29. Neeli I, Khan SN, Radic M: Histone deimination as a response to inflammatory stimuli in neutrophils. J Immunol 2008, 180:1895-1902.

30. Kolls JK, Linden A: Interleukin-17 family members and inflammation. Immunity 2004, 21:467-476.

31. Scapini P, Bazzoni F, Cassatella MA: Regulation of B-cell-activating factor (BAFF)/B lymphocyte stimulator (BLyS) expression in human neutrophils. Immunol Lett 2008, 116:1-6.

32. El Kebir D, Filep JG: Modulation of neutrophil apoptosis and the resolution of inflammation through beta2 integrins. Front Immunol 2013, 4:60.

33. Pillay J, den Braber I, Vrisekoop N, Kwast LM, de Boer RJ, Borghans JA, Tesselaar $\mathrm{K}$, Koenderman $\mathrm{L}$ : In vivo labeling with $2 \mathrm{H} 2 \mathrm{O}$ reveals a human neutrophil lifespan of 5.4 days. Blood 2010, 116:625-627.

34. Franssen CF, Huitema MG, Muller Kobold AC, Oost-Kort WW, Limburg PC, Tiebosch A, Stegeman CA, Kallenberg CG, Tervaert JW: In vitro neutrophil activation by antibodies to proteinase 3 and myeloperoxidase from patients with crescentic glomerulonephritis. J Am Soc Nephrol 1999, 10:1506-1515

35. Witko-Sarsat V, Lesavre P, Lopez S, Bessou G, Hieblot C, Prum B, Noel LH, Guillevin L, Ravaud P, Sermet-Gaudelus I, Timsit J, Grünfeld JP, Halbwachs-Mecarelli L: A large subset of neutrophils expressing membrane proteinase 3 is a risk factor for vasculitis and rheumatoid arthritis. J Am Soc Nephrol 1999, 10:1224-1233.

36. Charles LA, Caldas ML, Falk RJ, Terrell RS, Jennette JC: Antibodies against granule proteins activate neutrophils in vitro. J Leukoc Biol 1991, 50:539-546.

37. Yang JJ, Preston GA, Pendergraft WF, Segelmark M, Heeringa P, Hogan SL, Jennette JC, Falk RJ: Internalization of proteinase 3 is concomitant with endothelial cell apoptosis and internalization of myeloperoxidase with generation of intracellular oxidants. Am J Pathol 2001, 158:581-592.

38. Porges AJ, Redecha PB, Kimberly WT, Csernok E, Gross WL, Kimberly RP: Anti-neutrophil cytoplasmic antibodies engage and activate human neutrophils via Fc gamma Rlla. J Immunol 1994, 153:1271-1280.

39. Kocher M, Edberg JC, Fleit HB, Kimberly RP: Antineutrophil cytoplasmic antibodies preferentially engage Fc gammaRIllb on human neutrophils. $J$ Immunol 1998, 161:6909-6914.

40. Williams JM, Ben-Smith A, Hewins P, Dove SK, Hughes P, McEwan R, Wakelam MJ, Savage CO: Activation of the G(i) heterotrimeric $G$ protein by ANCA lgG $F\left(a b^{\prime}\right) 2$ fragments is necessary but not sufficient to stimulate the recruitment of those downstream mediators used by intact ANCA IgG. J Am Soc Nephrol 2003, 14:661-669.

41. Xiao H, Heeringa P, Hu P, Liu Z, Zhao M, Aratani Y, Maeda N, Falk RJ, Jennette JC: Antineutrophil cytoplasmic autoantibodies specific for myeloperoxidase cause glomerulonephritis and vasculitis in mice. $J$ Clin Invest 2002, 110:955-963.

42. Schreiber A, Xiao H, Falk RJ, Jennette JC: Bone marrow-derived cells are sufficient and necessary targets to mediate glomerulonephritis and vasculitis induced by anti-myeloperoxidase antibodies. J Am Soc Nephrol 2006, 17:3355-3364.

43. Pfister H, Ollert M, Frohlich LF, Quintanilla-Martinez L, Colby TV, Specks U, Jenne DE: Antineutrophil cytoplasmic autoantibodies against the murine homolog of proteinase 3 (Wegener autoantigen) are pathogenic in vivo. Blood 2004, 104:1411-1418.

44. Kain R, Matsui K, Exner M, Binder S, Schaffner G, Sommer EM, Kerjaschki D: A novel class of autoantigens of anti-neutrophil cytoplasmic antibodies in necrotizing and crescentic glomerulonephritis: the lysosomal membrane glycoprotein h-lamp-2 in neutrophil granulocytes and a related membrane protein in glomerular endothelial cells. J Exp Med 1995, 181:585-597.

45. Kain R, Exner M, Brandes R, Ziebermayr R, Cunningham D, Alderson CA, Davidovits A, Raab I, Jahn R, Ashour O, Spitzauer S, Sunder-Plassmann G, Fukuda M, Klemm P, Rees AJ, Kerjaschki D: Molecular mimicry in pauci-immune focal necrotizing glomerulonephritis. Nat Med 2008, 14:1088-1096.

46. Gabillet J, Millet A, Pederzoli-Ribeil M, Tacnet-Delorme P, Guillevin L, Mouthon L, Frachet $P$, Witko-Sarsat V: Proteinase 3, the autoantigen in granulomatosis with polyangiitis, associates with calreticulin on 
apoptotic neutrophils, impairs macrophage phagocytosis, and promotes inflammation. J Immunol 2012, 189:2574-2583.

47. Hong Y, Eleftheriou D, Hussain AA, Price-Kuehne FE, Savage CO, Jayne D, Little MA, Salama AD, Klein NJ, Brogan PA: Anti-neutrophil cytoplasmic antibodies stimulate release of neutrophil microparticles. J Am Soc Nephrol 2012, 23:49-62.

48. Holden NJ, Williams JM, Morgan MD, Challa A, Gordon J, Pepper RJ, Salama $A D$, Harper L, Savage CO: ANCA-stimulated neutrophils release BLyS and promote B cell survival: a clinically relevant cellular process. Ann Rheum Dis 2011, 70:2229-2233.

49. Kessenbrock K, Krumbholz M, Schonermarck U, Back W, Gross WL, Werb Z, Grone HJ, Brinkmann V, Jenne DE: Netting neutrophils in autoimmune small-vessel vasculitis. Nat Med 2009, 15:623-625.

50. Nakazawa D, Tomaru U, Suzuki A, Masuda S, Hasegawa R, Kobayashi T, Nishio S, Kasahara M, Ishizu A: Abnormal conformation and impaired degradation of propylthiouracil-induced neutrophil extracellular traps: implications of disordered neutrophil extracellular traps in a rat model of myeloperoxidase antineutrophil cytoplasmic antibody-associated vasculitis. Arthritis Rheum 2012, 64:3779-3787.

51. Sangaletti S, Tripodo C, Chiodoni C, Guarnotta C, Cappetti B, Casalini P, Piconese S, Parenza M, Guiducci C, Vitali C, Colombo MP: Neutrophil extracellular traps mediate transfer of cytoplasmic neutrophil antigens to myeloid dendritic cells toward ANCA induction and associated autoimmunity. Blood 2012, 120:3007-3018.

52. Brandt L, Hedberg H: Impaired phagocytosis by peripheral blood granulocytes in systemic lupus erythematosus. Scand J Haematol 1969, 6:348-353.

53. Abramson SB, Given WP, Edelson HS, Weissmann G: Neutrophil aggregation induced by sera from patients with active systemic lupus erythematosus. Arthritis Rheum 1983, 26:630-636.

54. Ronnefarth VM, Erbacher Al, Lamkemeyer T, Madlung J, Nordheim A Rammensee HG, Decker P: TLR2/TLR4-independent neutrophil activation and recruitment upon endocytosis of nucleosomes reveals a new pathway of innate immunity in systemic lupus erythematosus. J Immunol 2006, 177:7740-7749.

55. Alves CM, Marzocchi-Machado CM, Louzada-Junior P, Azzolini AE, Polizello AC, de Carvalho IF, Lucisano-Valim YM: Superoxide anion production by neutrophils is associated with prevalent clinical manifestations in systemic lupus erythematosus. Clin Rheumatol 2008, 27:701-708.

56. Vordenbaumen S, Fischer-Betz R, Timm D, Sander O, Chehab G, Richter J, Bleck E, Schneider M: Elevated levels of human beta-defensin 2 and human neutrophil peptides in systemic lupus erythematosus. Lupus 2010 19:1648-1653.

57. Armstrong DJ, Crockard AD, Wisdom BG, Whitehead EM, Bell AL Accelerated apoptosis in SLE neutrophils cultured with anti-dsDNA antibody isolated from SLE patient serum: a pilot study. Rheumatol Int 2006, 27:153-156.

58. Donnelly S, Roake W, Brown S, Young P, Naik H, Wordsworth P, Isenberg $D A$, Reid KB, Eggleton P: Impaired recognition of apoptotic neutrophils by the $\mathrm{C} 1 \mathrm{q} /$ calreticulin and CD91 pathway in systemic lupus erythematosus. Arthritis Rheum 2006, 54:1543-1556.

59. Schorn C, Janko C, Krenn V, Zhao Y, Munoz LE, Schett G, Herrmann M: Bonding the foe - NETting neutrophils immobilize the pro-inflammatory monosodium urate crystals. Front Immunol 2012, 3:376.

60. Knight JS, Kaplan MJ: Lupus neutrophils: 'NET' gain in understanding lupus pathogenesis. Curr Opin Rheumatol 2012, 24:441-450.

61. Kaplan MJ: Neutrophils in the pathogenesis and manifestations of SLE. Nat Rev Rheumatol 2011, 7:691-699.

62. Bennett L, Palucka AK, Arce E, Cantrell V, Borvak J, Banchereau J, Pascual V: Interferon and granulopoiesis signatures in systemic lupus erythematosus blood. J Exp Med 2003, 197:711-723.

63. Denny MF, Yalavarthi S, Zhao W, Thacker SG, Anderson M, Sandy AR, McCune WJ, Kaplan MJ: A distinct subset of proinflammatory neutrophils isolated from patients with systemic lupus erythematosus induces vascular damage and synthesizes type I IFNs. J Immunol 2010, 184:3284-3297.

64. Carmona-Rivera C, Kaplan MJ: Low-density granulocytes: a distinct class of neutrophils in systemic autoimmunity. Semin Immunopathol 2013, 35:455-463.

65. Villanueva E, Yalavarthi S, Berthier CC, Hodgin JB, Khandpur R, Lin AM, Rubin CJ, Zhao W, Olsen SH, Klinker M, Shealy D, Denny MF, Plumas J, Chaperot L,
Kretzler M, Bruce AT, Kaplan MJ: Netting neutrophils induce endothelial damage, infiltrate tissues, and expose immunostimulatory molecules in systemic lupus erythematosus. J Immunol 2011, 187:538-552.

66. Nakou M, Bertsias G, Stagakis I, Centola M, Tassiulas I, Hatziapostolou M, Kritikos I, Goulielmos G, Boumpas DT, Iliopoulos D: Gene network analysis of bone marrow mononuclear cells reveals activation of multiple kinase pathways in human systemic lupus erythematosus. PLoS One 2010, 5:e13351.

67. Garcia-Romo GS, Caielli S, Vega B, Connolly J, Allantaz F, Xu Z, Punaro M, Baisch J, Guiducci C, Coffman RL, Barrat FJ, Banchereau J, Pascual V: Netting neutrophils are major inducers of type I IFN production in pediatric systemic lupus erythematosus. Sci Trans/ Med 2011, 3:73ra20.

68. Hakkim A, Furnrohr BG, Amann K, Laube B, Abed UA, Brinkmann V, Herrmann M, Voll RE, Zychlinsky A: Impairment of neutrophil extracellular trap degradation is associated with lupus nephritis. Proc Natl Acad Sci U S A 2010, 107:9813-9818

69. Lande R, Ganguly D, Facchinetti V, Frasca L, Conrad C, Gregorio J, Meller S, Chamilos G, Sebasigari R, Riccieri V, Bassett R, Amuro H, Fukuhara S, Ito T, Liu YJ, Gilliet M: Neutrophils activate plasmacytoid dendritic cells by releasing self-DNA-peptide complexes in systemic lupus erythematosus. Sci Transl Med 2011, 3:73ra19.

70. Leffler J, Martin M, Gullstrand B, Tyden H, Lood C, Truedsson L, Bengtsson AA, Blom AM: Neutrophil extracellular traps that are not degraded in systemic lupus erythematosus activate complement exacerbating the disease. J Immunol 2012, 188:3522-3531.

71. Kahlenberg JM, Carmona-Rivera C, Smith CK, Kaplan MJ: Neutrophil extracellular trap-associated protein activation of the NLRP3 inflammasome is enhanced in lupus macrophages. J Immunol 2013, 190:1217-1226.

72. Liu CL, Tangsombatvisit S, Rosenberg JM, Mandelbaum G, Gillespie EC, Gozani OP, Alizadeh AA, Utz PJ: Specific post-translational histone modifications of neutrophil extracellular traps as immunogens and potential targets of lupus autoantibodies. Arthritis Res Ther 2012, 14:R25.

73. Campbell AM, Kashgarian M, Shlomchik MJ: NADPH oxidase inhibits the pathogenesis of systemic lupus erythematosus. Sci Trans/ Med 2012, 4:157ra141.

74. Grimm MJ, Vethanayagam RR, Almyroudis NG, Dennis CG, Khan AN, D'Auria AC, Singel KL, Davidson BA, Knight PR, Blackwell TS, Hohl TM, Mansour MK Vyas JM, Röhm M, Urban CF, Kelkka T, Holmdahl R, Segal BH: Monocyteand macrophage-targeted NADPH oxidase mediates antifungal host defense and regulation of acute inflammation in mice. J Immuno/ 2013, 190:4175-4184.

75. Meissner F, Seger RA, Moshous D, Fischer A, Reichenbach J, Zychlinsky A Inflammasome activation in NADPH oxidase defective mononuclear phagocytes from patients with chronic granulomatous disease. Blood 2010, 116:1570-1573.

76. Pilsczek FH, Salina D, Poon KK, Fahey C, Yipp BG, Sibley CD, Robbins SM, Green FH, Surette MG, Sugai M, Bowden MG, Hussain M, Zhang K, Kubes P. A novel mechanism of rapid nuclear neutrophil extracellular trap formation in response to Staphylococcus aureus. J Immunol 2010, 185:7413-7425.

77. Chow OA, von Kockritz-Blickwede M, Bright AT, Hensler ME, Zinkernagel AS, Cogen AL, Gallo RL, Monestier M, Wang Y, Glass CK, Nizet V: Statins enhance formation of phagocyte extracellular traps. Cell Host Microbe 2010, 8:445-454.

78. Hoffmann MH, Bruns H, Backdahl L, Neregard P, Niederreiter B, Herrmann M, Catrina Al, Agerberth B, Holmdahl R: The cathelicidins LL-37 and rCRAMP are associated with pathogenic events of arthritis in humans and rats. Ann Rheum Dis 2013, 72:1239-1248.

79. Knight JS, Zhao W, Luo W, Subramanian V, O'Dell AA, Yalavarthi S, Hodgin $J B$, Eitzman DT, Thompson PR, Kaplan MJ: Peptidylarginine deiminase inhibition is immunomodulatory and vasculoprotective in murine lupus. J Clin Invest 2013, 123:2981-2993.

80. Mehrad B, Park SJ, Akangire G, Standiford TJ, Wu T, Zhu J, Mohan C: The lupus-susceptibility locus, Sle3, mediates enhanced resistance to bacterial infections. J Immunol 2006, 176:3233-3239.

81. den Broeder AA, Wanten GJ, Oyen WJ, Naber T, van Riel PL, Barrera P: Neutrophil migration and production of reactive oxygen species during treatment with a fully human anti-tumor necrosis factor-alpha monoclonal antibody in patients with rheumatoid arthritis. J Rheumatol 2003, 30:232-237. 
82. Dularay B, Badesha JS, Dieppe PA, Elson CJ: Oxidative response of polymorphonuclear leucocytes to synovial fluids from patients with rheumatoid arthritis. Ann Rheum Dis 1990, 49:661-664.

83. Dularay B, Elson CJ, Dieppe PA: Enhanced oxidative response of polymorphonuclear leukocytes from synovial fluids of patients with rheumatoid arthritis. Autoimmunity 1988, 1:159-169.

84. Kitsis $\mathrm{E}$, Weissmann G: The role of the neutrophil in rheumatoid arthritis. Clin Orthop Relat Res 1991, 265:63-72.

85. Pillinger MH, Abramson SB: The neutrophil in rheumatoid arthritis. Rheum Dis Clin North Am 1995, 21:691-714.

86. Barnhart Ml, Riddle JM, Bluhm GB: Immunocytology in arthritic joints. Ann Rheum Dis 1967, 26:281-296.

87. Belcher C, Doherty M, Crouch SP: Synovial fluid neutrophil function in RA: the effect of pregnancy associated proteins. Ann Rheum Dis 2002. 61:379-380

88. Hughes JR, Erhardt CC, Clement M: Neutrophilic dermatosis in association with rheumatoid arthritis. Clin Exp Dermatol 1995, 20:168-170.

89. Ichikawa MM, Murata Y, Higaki Y, Kawashima M, Furuya T, Saito T: Rheumatoid neutrophilic dermatitis. Eur J Dermatol 1998, 8:347-349.

90. Cines DB, Passero F, Guerry D 4th, Bina M, Dusak B, Schreiber AD: Granulocyte-associated IgG in neutropenic disorders. Blood 1982, 59:124-132

91. Coremans IE, Hagen EC, van der Voort EA, van der Woude FJ, Daha MR, Breedveld FC: Autoantibodies to neutrophil cytoplasmic enzymes in Felty's syndrome. Clin Exp Rheumatol 1993, 11:255-262.

92. Lassoued S, Sixou L, Oksman F, Pages M, Fournie A: Antineutrophil cytoplasmic antibodies and antibodies to myeloperoxidase in rheumatoid arthritis. Arthritis Rheum 1991, 34:1069-1070.

93. Wipke BT, Allen PM: Essential role of neutrophils in the initiation and progression of a murine model of rheumatoid arthritis. J Immunol 2001, 167:1601-1608.

94. Gal I, Bajnok E, Szanto S, Sarraj B, Glant TT, Mikecz K: Visualization and in situ analysis of leukocyte trafficking into the ankle joint in a systemic murine model of rheumatoid arthritis. Arthritis Rheum 2005, 52:3269-3278.

95. Griffiths RJ, Pettipher ER, Koch K, Farrell CA, Breslow R, Conklyn MJ, Smith MA, Hackman BC, Wimberly DJ, Milici AJ, Scampoli DN, Cheng JB, Pillar JS, Pazoles CJ, Doherty NS, Melvin LS, Reiter LA, Biggars MS, Falkner FC, Mitchell DY, Liston TE, Showell HJ: Leukotriene B4 plays a critical role in the progression of collagen-induced arthritis. Proc Natl Acad Sci U S A 1995, 92:517-521.

96. Matsubara S, Yamamoto T, Tsuruta T, Takagi K, Kambara T: Complement C4-derived monocyte-directed chemotaxis-inhibitory factor. A molecular mechanism to cause polymorphonuclear leukocyte-predominant infiltration in rheumatoid arthritis synovial cavities. Am J Pathol 1991 , 138:1279-1291.

97. Brennan FM, Zachariae CO, Chantry D, Larsen CG, Turner M, Maini RN, Matsushima K, Feldmann M: Detection of interleukin 8 biological activity in synovial fluids from patients with rheumatoid arthritis and production of interleukin 8 mRNA by isolated synovial cells. Eur J Immunol 1990 20:2141-2144

98. Sadik CD, Kim ND, Iwakura Y, Luster AD: Neutrophils orchestrate their own recruitment in murine arthritis through $\mathrm{C} 5 \mathrm{aR}$ and FcgammaR signaling. Proc Natl Acad Sci U S A 2012, 109:E3177-E3185.

99. Eyles JL, Hickey MJ, Norman MU, Croker BA, Roberts AW, Drake SF, James WG, Metcalf D, Campbell IK, Wicks IP: A key role for G-CSF-induced neutrophil production and trafficking during inflammatory arthritis. Blood 2008, 112:5193-5201

100. Cook AD, Turner AL, Braine EL, Pobjoy J, Lenzo JC, Hamilton JA: Regulation of systemic and local myeloid cell subpopulations by bone marrow cell-derived granulocyte-macrophage colony-stimulating factor in experimental inflammatory arthritis. Arthritis Rheum 2011, 63:2340-2351.

101. Cascão R, Moura RA, Perpétuo I, Canhão H, Vieira-Sousa E, Mourão AF, Rodrigues AM, Polido-Pereira J, Queiroz MV, Rosário HS, Souto-Carneiro MM, Graca L, Fonseca JE: Identification of a cytokine network sustaining neutrophil and Th17 activation in untreated early rheumatoid arthritis. Arthritis Res Ther 2010, 12:R196.

102. Chen M, Lam BK, Luster AD, Zarini S, Murphy RC, Bair AM, Soberman RJ, Lee DM: Joint tissues amplify inflammation and alter their invasive behavior via leukotriene B4 in experimental inflammatory arthritis. J Immunol 2010, 185:5503-5511.
103. Vossenaar ER, Nijenhuis S, Helsen MM, van der Heijden A, Senshu T, van den Berg WB, van Venrooij WJ, Joosten LA: Citrullination of synovial proteins in murine models of rheumatoid arthritis. Arthritis Rheum 2003, $48: 2489-2500$

104. Caccavo D, Garzia P, Sebastiani GD, Ferri GM, Galluzzo S, Vadacca M, Rigon A, Afeltra A, Amoroso A: Expression of lactoferrin on neutrophil granulocytes from synovial fluid and peripheral blood of patients with rheumatoid arthritis. J Rheumatol 2003, 30:220-224.

105. Corberand J, Amigues $\mathrm{H}$, de Larrard B, Pradere J: Neutrophil function in rheumatoid arthritis. Scand J Rheumatol 1977, 6:49-52.

106. Chatham WW, Heck LW, Blackburn WD Jr: Lysis of fibrillar collagen by neutrophils in synovial fluid. A role for surface-bound immunoglobulins. Arthritis Rheum 1990, 33:1333-1339.

107. Emery P, Lopez AF, Burns GF, Vadas MA: Synovial fluid neutrophils of patients with rheumatoid arthritis have membrane antigen changes that reflect activation. Ann Rheum Dis 1988, 47:34-39.

108. Mohr W, Wessinghage D: The relationship between polymorphonuclear granulocytes and cartilage destruction in rheumatoid arthritis. Z Rheumatol 1978, 37:81-86.

109. Cross A, Barnes T, Bucknall RC, Edwards SW, Moots RJ: Neutrophil apoptosis in rheumatoid arthritis is regulated by local oxygen tensions within joints. J Leukoc Biol 2006, 80:521-528.

110. Chakravarti A, Raquil MA, Tessier P, Poubelle PE: Surface RANKL of Toll-like receptor 4-stimulated human neutrophils activates osteoclastic bone resorption. Blood 2009, 114:1633-1644.

111. Poubelle PE, Chakravarti A, Fernandes MJ, Doiron K, Marceau AA: Differential expression of RANK, RANK-L, and osteoprotegerin by synovial fluid neutrophils from patients with rheumatoid arthritis and by healthy human blood neutrophils. Arthritis Res Ther 2007, 9:R25.

112. Dominical VM, Bertolo MB, Almeida CB, Garrido VT, Miguel LI, Costa FF, Conran N: Neutrophils of rheumatoid arthritis patients on anti-TNF-alpha therapy and in disease remission present reduced adhesive functions in association with decreased circulating neutrophil-attractant chemokine levels. Scand J Immunol 2011, 73:309-318.

113. Khandpur R, Carmona-Rivera C, Vivekanandan-Giri A, Gizinski A, Yalavarthi S, Knight JS, Friday S, Li S, Patel RM, Subramanian V, Thompson P, Chen P, Fox DA, Pennathur S, Kaplan MJ: NETs are a source of citrullinated autoantigens and stimulate inflammatory responses in rheumatoid arthritis. Sci Trans/ Med 2013, 5:178ra140

114. Cesaro A, Anceriz N, Plante A, Page N, Tardif MR, Tessier PA: An inflammation loop orchestrated by $\mathrm{S100A9}$ and calprotectin is critical for development of arthritis. PLoS One 2012, 7:e45478.

115. Turesson C, Mathsson L, Jacobsson LT, Sturfelt G, Ronnelid J: Antibodies to modified citrullinated vimentin are associated with severe extra-articular manifestations in rheumatoid arthritis. Ann Rheum Dis 2013 [Epub ahead of print].

116. Willis VC, Gizinski AM, Banda NK, Causey CP, Knuckley B, Cordova KN, Luo Y, Levitt B, Glogowska M, Chandra P, Kulik L, Robinson WH, Arend WP, Thompson PR, Holers VM: N-alpha-benzoyl-N5-(2-chloro-1-iminoethyl)-Lornithine amide, a protein arginine deiminase inhibitor, reduces the severity of murine collagen-induced arthritis. J Immunol 2011, 186:4396-4404.

117. Rohrbach AS, Hemmers S, Arandjelovic S, Corr M, Mowen KA: PAD4 is not essential for disease in the $\mathrm{K} / \mathrm{BxN}$ murine autoantibody-mediated model of arthritis. Arthritis Res Ther 2012, 14:R104.

118. Dwivedi N, Upadhyay J, Neeli I, Khan S, Pattanaik D, Myers L, Kirou KA, Hellmich B, Knuckley B, Thompson PR, Crow MK, Mikuls TR, Csernok E, Radic M: Felty's syndrome autoantibodies bind to deiminated histones and neutrophil extracellular chromatin traps. Arthritis Rheum 2012, 64:982-992.

10.1186/ar4325

Cite this article as: Kaplan: Role of neutrophils in systemic autoimmune diseases. Arthritis Research \& Therapy 2013, 15:219 